\title{
Postnatal Development of Blood Serum Concentrations of Immunoglobulin IgG, IgA and IgM Isotypes in Suckling Foals
}

\author{
M. SEDLINSKÁ ${ }^{1}$, J. KREJČÍ ${ }^{2}$, M. VYSKOČIL ${ }^{1}$, H. KUDLÁČKOVÁ ${ }^{2}$ \\ ${ }^{1}$ University of Veterinary and Pharmaceutical Sciences Brno, Czech Republic \\ ${ }^{2}$ Veterinary Research Institute Brno, Czech Republic \\ Received December 9, 2004 \\ Accepted March 16, 2006
}

\begin{abstract}
Sedlinská M, J. Krejčí, M. Vyskočil, H. Kudláčková: Postnatal Development of Blood Serum Concentrations of Immunoglobulin IgG, IgA and IgM Isotypes in Suckling Foals. Acta Vet. Brno 2006, 75: 175-182.

Postnatal changes in concentrations of immunoglobulin $\operatorname{IgG}$, IgM and IgA isotypes from birth until the age of five months were monitored by the ELISA method. The experiment was performed in a group of 52 thoroughbred foals and their mothers. Among the investigated animals, failure of colostral immunity transfer was recorded in only four foals ( 7.7 percent). The concentrations of immunoglobulin IgG and IgA isotypes primarily decreased during the first weeks of life and then gradually increased until the end of the investigated period. The concentrations of immunoglobulin $\mathrm{IgG}$ isotype reached the values of adult animals by the end of the investigated period. However, immunoglobulin IgA isotype did not reach those values during the entire investigated period. The concentrations of immunoglobulin IgM isotype were quite rapidly increasing from the birth on. The beginning of active antibody formation was inversely proportional to the level of colostral immunoglobulins.
\end{abstract}

$\operatorname{IgG}, \operatorname{IgA}$, IgM, foals, colostral immunity, postnatal changes

After foetal development in the sterile environment of uterus, the foals are exposed to a wide spectrum of microorganisms immediately after birth, although their immune system is not able to respond adequately. Due to the fact that horses have a diffuse epitheliochorial placenta through which molecules of immunoglobulins are not able to penetrate to foetal blood, the foals are born agammaglobulinemic. Moreover, the immune system of foals at birth is not fully mature, and therefore it is able to react to antigenic stimulation only with moderate immune response including limited antibody formation (Tizard 2000). The key role, which is decisive for the foal survival is therefore ascribed to maternal antibodies passively obtained with colostrum (Jeffcott 1972; Perry man 1981).

Immediately after the first colostrum intake, immunoglobulin serum concentrations reach values similar to those present in sera of the dams (Naylor 1979). Under common conditions, when the foal consumes colostrum during the first two hours of life, maximum values of serum IgG can be registered between 12 and $18 \mathrm{~h}$ after birth and the values are usually 8 to $21 \mathrm{~g} \cdot \mathrm{l}^{-1}$ (Rossdale 1967; Jeffcott 1972). However, passively obtained antibodies undergo catabolic degradation immediately after absorption. Moreover, they are diluted with increasing blood plasma volume (Jeffcott 1971; Naylor 1979; Spensley et al. 1987). Natural decrease of blood serum immunoglobulin levels in newborn foals is compensated by early onset of their own antibody formation. It is a result of the response to antigenic stimuli from external environment. The first signs of the antibody formation by foal organism may be already detected at the age of two weeks (Jeffcott 1974). Despite that fact, blood serum immunoglobulin concentrations decrease until the age of 1 to 2 months, when the own active immunoglobulin synthesis prevails over natural decay. The total level of blood serum immunoglobulin increases gradually only after that period. Values

Address for correspondence:

MVDr. Markéta Sedlinská

University of Veterinary and Pharmaceutical Sciences

Palackého 1-3, 61242 Brno

Czech Republic
Phone: +420 541562574

Fax:+420 541562395

E- mail: sedlinskam@vfu.cz

http://www.vfu.cz/acta-vet/actavet.htm 
comparable with those in the adult horses are not reached before the age of 4 to 6 months (Morgan 1973; Jeffcott 1971, 1974; Crawford and Perryman 1980). On the other hand, Rouse (1971) investigating the development dynamics of respective immunoglobulin isotypes in foals, recorded that $\operatorname{IgM}$ antibody concentrations reached the values of the adults already at the age of 4 to 6 months; however, $\mathrm{IgG}$ concentrations did not reach those values until 10 months of age. Likewise Ek (1974) did not detect values comparable to those in the adults until the age of 3 to 4 years.

Foals that did not ingest colostrum showed almost total agamaglobulinemia in the first two weeks of life. Increasing concentrations of immunoglobulins can be detected in these animals from 14 to 24 days of life (Jeffcott 1974; McGuire and Crawford 1973). Antibody formation rapidly increases after the end of this period and so, at the age of five weeks, their concentrations almost do not differ from immunoglobulin concentrations in foals that ingested colostrum. It follows that the increase in IgG values is more marked in foals without colostral antibodies compared to those that ingested a sufficient amount of colostrum (McGuire and Crawford 1973).

The studies dealing with developmental changes in immunoglobulin concentrations in foals cited above were predominantly focused on immunoglobulin IgG isotype. The aim of the present study was to extend current knowledge of concentrations of the three main immunoglobulin isotypes ( $\operatorname{IgG}, \operatorname{IgA}$ and $\operatorname{IgM}$ ) in neonatal foals and their mothers and to subsequently describe their developmental changes in suckling foals.

\section{Material and Methods}

Experimental animals

Fifty-two thoroughbred mares and their foals (24 females and 28 males), reared on the same farm were tested in the current study. All the foals spontaneously ingested colostrum during 3 hours after birth. Specific gravity of colostrum from all the mares was higher than $1.040 \mathrm{~g} . \mathrm{ml}^{-1}$. No prophylactic medication was given to the foals.

Blood collection and processing

Blood was collected by puncture of $\mathrm{v}$. jugularis. Blood sera obtained by a conventional procedure were frozen and stored at $-80^{\circ} \mathrm{C}$ before they were examined together for the contents of respective immunoglobulin isotypes. Blood was taken from each mare 24 to $30 \mathrm{~h}$ post partum. The foals were sampled four times as follows: at the age of 24 to $30 \mathrm{~h}, 21$ to 28 days, 2 months and 5 months.

Concentrations of immunoglobulin isotypes $\operatorname{IgG}, \operatorname{Ig}$ M and Ig A

Concentrations of IgG, IgM and IgA in blood serum samples were determined by standard ELISA method using the kits for quantitative determination of equine immunoglobulins IgG, IgA and IgM (Bethyl, USA). The standard procedure was conducted according to the manufacturer's instructions. The results were obtained by ELISA reader iEMS (Labsystems) measurements and evaluated using the calibration curve prepared by assessment of standard samples included in the kits.

Statistical evaluation of the results

Median values and their deviations (quartiles) and minimum and maximum values were calculated for concentrations of respective immunoglobulin isotypes in all intervals monitored. Significance of the differences between concentrations of immunoglobulin isotypes in mares and foals at the end of the experiment ( 5 months of age) was also evaluated using the parametric non-paired $t$-test. The normal distribution of data was confirmed before. The relationships between respective values of immunoglobulin isotypes of individual foals and their dams were expressed as correlation coefficients. Calculations were performed using a statistical software package Microsoft Excel and Stat Plus (Matoušková et al. 1992). For better discrimination between the types of developmental dynamics of the respective immunoglobulin isotype concentrations, two groups of foals with significantly different IgG concentrations at the beginning of the study were selected from all investigated animals. Group A comprised 8 foals with the lowest initial IgG concentrations $\left(1.5\right.$ to $\left.11 \mathrm{~g} .1^{-1}\right)$. Group B comprised 8 foals with the highest initial IgG concentrations that ranged between 20.8 and $27.2 \mathrm{~g} .1^{-1}$ after the first intake of colostrum.

\section{Results}

Results concerning postnatal developmental changes in immunoglobulin concentrations of respective isotypes in foals are summarized in Figures 1 to 3 . They show variables of distribution of individual animal concentrations of the main immunoglobulin classes 


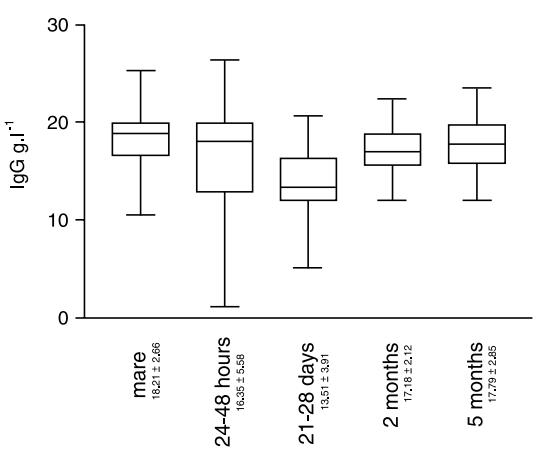

Fig.1. Developmental changes of median values of immunoglobulin IgG isotype concentrations in 52 newborn foals and their mares in time of the delivery.

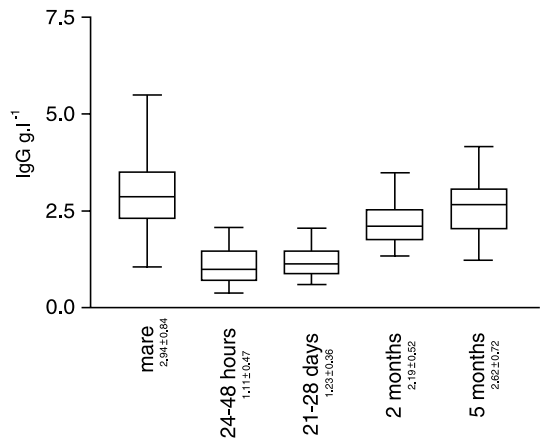

Fig.2. Developmental changes of median values of immunoglobulin IgM isotype concentrations in 52 newborn foals and their mares in time of the delivery.

(median, percentile, and ranges of minimum and maximum values) in the mares and their progeny in four intervals from the first colostrum intake up to the age of five months.

Immunoglobulin $\mathrm{IgG}$ isotype

It is evident from the results shown in Fig. 1 that immunoglobulin IgG isotype concentrations in 24- to 30-h-old foals did not differ from IgG concentrations detected in blood of their mothers. If the relationships between the pair values of mare - foal are considered, IgG levels in foals after colostrum intake were higher than in the respective dams in twenty cases $(38.5 \%)$. In the other cases, IgG concentrations in foals after colostrum intake were lower than in their mothers. However, in general, both values showed a significant positive correlation $(\mathrm{r}=0.292, p<0.01)$.

IgG concentrations lower than $8 \mathrm{~g}^{-1^{-1}}$, which is considered as a threshold value of successful transfer of maternal antibodies, were detected in four foals only (7.7\%). Later changes in the concentrations of IgG isotype immunoglobulins are characterized by a decrease during the following weeks (measured 3 to 4 weeks after the colostrum intake). Average concentrations of IgG immunoglobulins significantly decline in that period and reach minimum values. Concentrations of this immunoglobulin isotype gradually rise in the subsequent intervals, and at the age of five months reach values not significantly different from those of adult animals.

Immunoglobulin IgM isotype

Unlike the IgG immunoglobulin isotype, immunoglobulin IgM average concentration changes are characterized by an increase from the very beginning of the investigated period (Fig. 2). Although the concentrations of immunoglobulin IgM isotype markedly increased during the whole investigated period, their concentrations did not approximate the values detected in their mothers until the age of five months.

\section{Immunoglobulin IgA isotype}

Developmental changes in immunoglobulin IgA isotype (Fig. 3) are similar to those of immunoglobulin IgG. They share the basic characteristics, i.e. post partum decline and later increase in concentrations. It is notable that the concentrations of this isotype in foals were significantly lower than in their mothers $(p<0.01)$ at the end $(5$ months of age $)$ of the investigated period. Despite that finding, comparison of the respective pairs of mother - foal showed positive correlations $(r=0.459, p<0.01)$.

Analytical evaluation of the above results

All measured values were summarized in the above-described results. They resulted from 


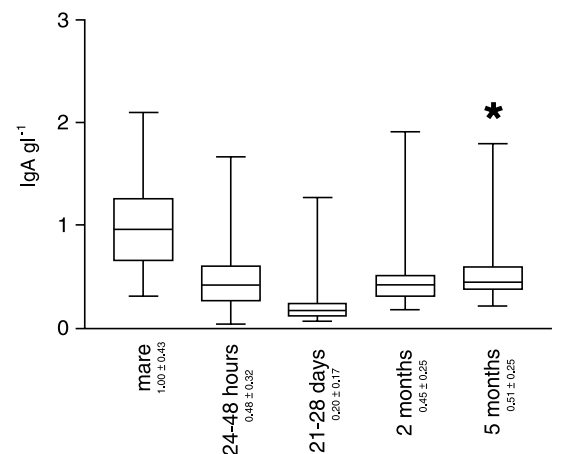

Fig. 3. Developmental changes of median values of immunoglobulin IgA isotype concentrations in 52 newborn foals and their mares at the time of the delivery (asterisk indicate significance of differences between concentrations of immunoglobulin isotypes in mares and foals at the end of the experiment). antagonistic activities: catabolic degradation of passively ingested colostral antibodies and their active formation. Various intensities of these processes differ in each foal depending on initial values of colostral immunoglobulin concentrations. We selected eight foals with the highest and eight foals with the lowest initial values of immunoglobulin IgG isotype that allowed discrimination between the mentioned trends. Different developmental patterns of respective immunoglobulin isotype concentrations in these two markedly different groups have been separately described in the present study.

Immunoglobulin concentrations of IgG class in each foal from both groups, and their postnatal changes are shown in Fig. 4. IgG concentrations in foals with the most successful transfer of immunoglobulins (group B) were decreasing until the age of two months (with one exception). In contrast, in animals with the lowest initial concentrations, immunoglobulins of this isotype (group A) obviously increased during the same period. It is notable that in the foals with initial IgG concentrations lower than 8 g. $l^{-1}$ considered as the critical threshold value of the success rate of passive transfer, their concentrations already increased during the first three weeks of life. IgG immunoglobulin concentrations in animals with initial values higher than the given threshold, slightly decreased during the same period. However, $\operatorname{IgG}$ concentrations markedly increased between week 3 and 8 of life in all the foals from this group. IgG concentrations in hypogammaglobulinemic animals not only increased up to the level of normoglobulinemic group, but their average values even exceeded them insignificantly.

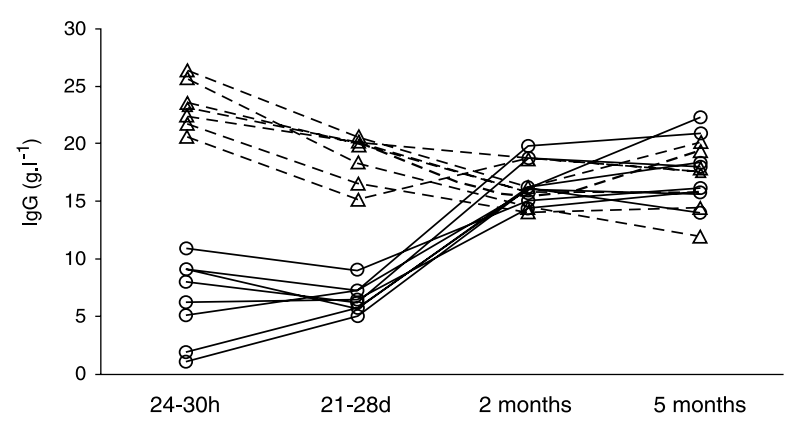

Fig. 4. Development of individual values of immunoglobulin IgG isotype concentrations in foals of two groups differing in initial values (Group A - 8 foals with lowest __ and group B - 8 foals with highest - - - values of IgG).

Developmental changes in the concentrations of immunoglobulin IgM isotype in each foal from two groups of animals, which markedly differ in the initial concentrations of immunoglobulin IgG isotype, are given in Fig. 5. It is evident that the initial concentrations of these isotype immunoglobulins follow the pattern, which most likely reflects the amount of colostrum ingested for the first time after birth. The highest initial concentrations of 


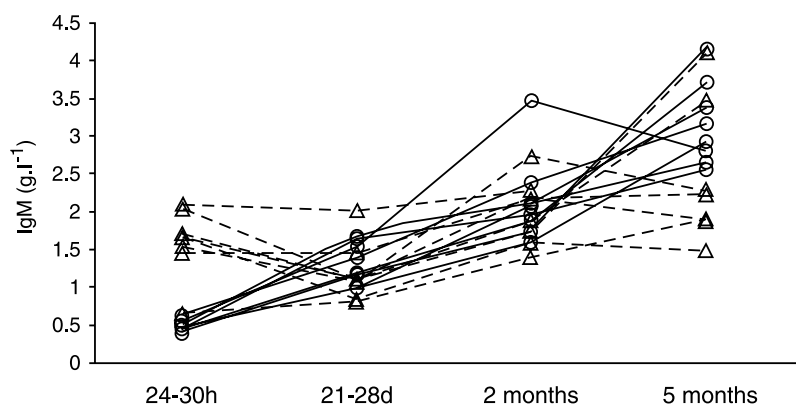

Fig. 5. Development of individual values of immunoglobulin $\operatorname{IgM}$ isotype concentrations in foals of two groups differing in initial values (Group A - 8 foals with lowest — and group B - 8 foals with highest - - - values of IgG).

immunoglobulins $\operatorname{IgM}$ were found in foals that ingested proper amounts of colostrum, whereas the lowest concentrations were detected in the compared group. Further developmental changes in both groups shared the pattern with the immunoglobulin $\operatorname{IgG}$ isotype, with slight variations only. After the initial decline during several first weeks, the concentrations of immunoglobulin IgM isotype in foals from group B increased and reached the values of adult animals in several cases. In the last investigated period, their concentrations were either further increasing or oscillated around the values reached in the previous period. In the foals from group A, an evident increase in immunoglobulin concentrations of this isotype was observed during the entire period after birth, and with one exception, persisted until the end of the investigated period when their levels exceeded average concentrations of adult animals.

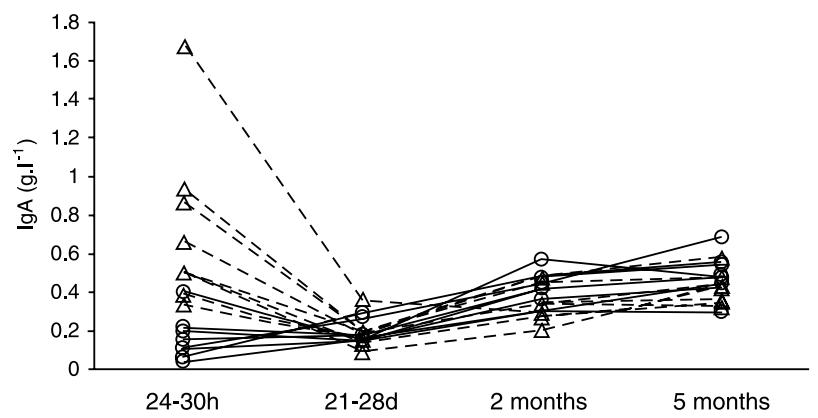

Fig. 6. Development of individual values of immunoglobulin $\operatorname{IgA}$ isotype concentrations in foals of two groups differing in initial values (Group A - 8 foals with lowest — and group B - 8 foals with highest - - - values of IgG).

Fig. 6 shows the development of the immunoglobulin IgA isotype concentrations in respective foals from the groups differing in the success rate of passive immunity transfer. Initial concentrations of this isotype in blood of newborn foals were rather low. Therefore, initial concentrations of this immunoglobulin isotype did not markedly differ among most of animals of both the groups. From the end of the first month after birth, when concentrations of immunoglobulin IgA in animals of both groups reached similar values, the trends of their further development were analogous. However, the concentrations were increasing slowly; the values of individual animals of both groups did not reach the average values of adult animals until the end of the investigated period in month 5 of life. 


\section{Discussion}

Among the presented results, it is most remarkable that the failure of colostral immunoglobulin transfer was recorded in a quite low percentage of foals. In the group of animals investigated in the present study, IgG immunoglobulin concentrations lower than $8 \mathrm{~g} . \mathrm{l}^{-1}$, considered as a threshold value indicating successful transfer of maternal immunity, were in 4 foals only. It corresponds to 7.7 percent from the total count of investigated animals. This finding is more favourable than the results presented by other authors (McGuire et al. 1977; Pemberton et al. 1980; Morris et al. 1985; Tyler-McGowan et al. 1997) who described a failure of passive transfer (FPT) of colostral immunoglobulin in 20 to $30 \%$ of newborn animals. The high rate of maternal immunity transfer in our study resulted mainly from a high standard of animal care in the herd where the animals were kept.

Further developmental changes in immunoglobulin concentrations in foals after birth are given by the interrelationship between catabolic degradation of passively ingested colostral antibodies and the onset of their own active formation. The courses of the curves depicting developmental changes in each immunoglobulin isotype level resulted from both processes. In the case of isotypes $\operatorname{IgG}$ and $\operatorname{IgA}$, their concentrations primarily decreased during the first two weeks of life. Later, they gradually increased during the remaining part of the whole investigated period. In the case of IgG isotype, they reached the concentrations characteristic of adult animals before the end of the study. However, immunoglobulins of IgA isotype did not reach those values throughout all this experiment. In contrast, increasing concentrations were characteristic of immunoglobulin IgM isotype from the very beginning of the investigation.

A different type of developmental changes in the concentrations of respective immunoglobulin isotypes is given particularly by their function and their proportion in colostrum. Antibodies of IgG isotype in colostrum constitute up to 70 percent (Tizard 2000). Majority of them are absorbed by active transport into circulating blood of newborn foals. Antibodies of this isotype protect the foals particularly from septicaemia and systemic infections; only a minor proportion of them also penetrate to the mucosal surfaces by means of neonatal receptor (Ghetie and W ard 2000). Among those, it is necessary to particularly mention respiratory tract mucosa (Sheoran et al. 2000). Further developmental changes in immunoglobulins of this isotype resulted from the development of antibody immune response.

Although colostrum of the mares comprises $20 \%$ of immunoglobulin IgA isotype, their absorption is limited because their primary function is to protect the digestive tract of newborn foals from infections with pathogenic microorganisms. Therefore, their blood concentrations in neonatal foals do not correspond to their proportion in colostrum and their further slow increase results from the fact that the majority of produced IgA antibodies are secreted to the mucosal surfaces. Initial low concentrations of antibodies of IgM isotype in the blood of newborn foals result from their low proportion in colostrum where they constitute less than $10 \%$. Their rapid increase during the first weeks of life corresponds to the fact that antibodies of this isotype prevail in the primary antibody response. This fact may be of great importance for early serodiagnosis of neonatal infections.

Separate investigation of the two groups of animals markedly differing in passive transfer success rate showed that newborn foals (like other ungulates) are able to respond by active antibody formation. It occurs mainly when they are not protected by specific maternal antibodies. In the first phase of postnatal development of antibody response, the key role is played by antibodies of IgM isotype and later, they are followed by active IgG antibody formation. In contrast, passive protection with specific colostral antibodies causes the delay in the onset of specific active antibody response. The delayed onset of active production of antibodies is most evident in IgG isotype. It results from the fact that the inhibition of active 
production of antibodies is specific for the respective isotypes. Due to the fact that the proportion of IgG isotype is the highest in colostrum, its inhibition is most marked. Investigation of dynamic changes of antibody response showed that IgG antibodies appeared after initial production of IgM antibodies. The proportion of IgM antibodies in colostrum is the lowest and accordingly, the inhibition of their active production is not marked. Nevertheless, in calves with low levels of maternal IgM antibodies in blood, the delay in their active production was evident.

That delay is primarily caused by a lower intensity of specific antigenic stimulation resulting from a rapid elimination of specific pathogens, and secondly by a mechanism inhibiting the specific immune response by blocking the activation of specific lymphocyte clones by specific antibodies (Tizard 2000).

Comparison of the results of the present study with the data previously described by other authors would be difficult, as those authors did not focus on the determination of respective immunoglobulin isotype levels (Morgan 1973; Jeffcott 1971, 1974; Crawford and Perryman 1980). Nevertheless, the results obtained in the present study are consistent with those of the mentioned authors, at least at the point of giving evidence of early beginning of active antibody formation. This resulted in reaching values comparable with adult animals already during the first six months of age of foals. However, they are inconsistent with the findings of Rouse (1971) and Ek (1974) who did not detect a marked increase in IgG immunoglobulin levels during the first year of age of foals. This finding remains unclear. The discrepancies between the results can hardly be explained by the fact that the mentioned authors used different methods.

\section{Postnatální vývoj koncentrace imunoglobulinů izotypů IgG, IgM a IgA u hř́bat}

Ve skupině 52 hř́ibat anglického plnokrevníka a jejich matek byl pomocí ELISA metody sledován postnatální vývoj hladin imunoglobulinủ izotypů IgG, IgM a IgA od narození až do stárí pěti měsícủ. Neúspěšný pasivní přenos kolostrální imunity byl ve sledovaném souboru zaznamenán jen u čtyř hř́ibat (7,7 procent). Koncentrace imunoglobulinů izotypů IgG a IgA v období prvních týdnů po porodu nejprve klesaly a posléze po celou sledovanou dobu postupně narưstaly. V př́padě izotypu IgG koncentrace imunoglobulinů dosáhly hodnot dospělých zviŕrat již před koncem sledovaného období. Imunoglobuliny IgA izotypu však těchto hodnot $\mathrm{v}$ průběhu celého sledovaného období nedosáhly. Koncentrace imunoglobulinů izotypu IgM relativně rychle narůstaly již od narození. Hř́ibata s nejnižšími počátečními hladinami kolostrálních imunoglobulinů vykazovala na konci sledovaného období nejvy̌šši nárůst hladin všech imunoglobulinových izotypů.

\section{Acknowledgements}

The study was supported by the Ministry of Agriculture of the Czech Republic (MZE-0002716201) and Ministry of Education, Youth and Sports of the Czech Republic (CEZ-J 16/98: 161700002)

\section{References}

CRAWFORD TB, PERRYMAN LE 1980: Diagnosis and treatment of failure of passive transfer in the foal. Equine Pract 2: 17-23

GHETIE V, WARD ES 2000: Multiple roles for the major histocompatibility complex class I-related receptor FcRn. Annu Rev Immunol 18: 739-766

EK N 1974: Serum levels of the immunoglobulins IgG and IgG(T) in horses. Acta Vet Scand 15: 609-619

JEFFCOTT LB 1971: Duration of permeability of intestine to macromolecules in the newly-born foals. Vet Rec 88: $340-341$

JEFFCOTT LB 1972: Passive immunity and transfer with special reference to the horse. Biol Rev 47: 439-464

JEFFCOTT LB 1974: Studies on the passive immunity in the foal: I. Gammaglobulin and antibody variations associated with the maternal transfer of immunity and the onset of active immunity. J Comp Path 84: 93-101

McGUIRE TC, CRAWFORD TB 1973: Passive immunity in the foal: measurement of immunoglobulin classes and specific antibody. Am J Vet Res 34: 1299-1303 
MORGAN DO 1973: Serum proteins of neonatal foals. Proc. $3^{\text {rd }}$ Int Conf Equine Infectious Diseases, pp.410-418

MORIS DD, MEIRS DA, MERRYMAN BS 1998: Passive transfer failure in horses: Incidence and causative factors on breeding farm. Am J Vet Res 46: 2294-2299

NAYLOR JM 1979: Colostral immunity in the calf and the foal. Vet Cli North Am (Large Anim Pract) 1: $331-361$

PEMBERTON DH, THOMAS KW, TERRY MJ 1980: Hypogammaglobulinemia in foals: prevalence on Victorian studs and simple methods for detection and correction in the field. Austr Vet J 56, 469-473

PERRYMAN LE 1981: Immunological management of young foals. Comp Cont Education Pract Vet 3: 223-228

ROSSDALE PD 1967: Clinical studies on newborn thoroughbred foal.1: Perinatal behaviour. Br Vet J 123: $470-481$

ROUSE BT 1971: The immunoglobulins of adult equine and foal sera: a quantitative study. Br Vet J 127: $45-52$

SHEORAN AS, TIMONEY JF, HOLMES MA, KARZENSKI SS, CRISMAN MV 2000: Immunoglobulin isotypes in sera and nasal mucosal secretions and their neonatal transfer and distribution in horses. AJVR 61: 1099-1105

SPENSLEY MS, CARLSON GP, HARROLD D 1987: Plasma, red blood cell, total blood and extracellular fluid volumes in healthy horse foals during growth. Am J Vet Res 48: 1703-1707

TIZARD IR 2000: Veterinary Immunology: An introduction. 6th Ed, W.B. Saunders

TYLER-McGOWAN CM, HODGSON JL, HODGSON DR 1997: Failure of passive transfer in foals: incidence and outcome on four studs in New South Wales. Aust Vet J 75: 56-59 